\title{
DIE VERBAND TUSSEN DIE SIELKUNDIGE KONTRAK EN ORGANISASIEVERBONDENHEID
}

\author{
K.J. STANZ, J.A. SLABBERT EN J.M. SCHEPERS \\ Departement Menslike Hulpbronbestuur, RAU
}

\begin{abstract}
The relationship between the psychological contract and organisational commitment. The aim of this study is to design a measuring instrument with acceptable metric characteristics for the strength of the psychological contract within the South African context, and to determine empirically the relation between the strength of the psychological contract and organisational commitment. The Dhammanungune Model served as foundation for the design of the Strength of the Psychological Contract Questionnaire which consists of two scales namely, a needs expectation scale and a needs fulfilment expectation scale. The items of each scale have been formulated in the manner that ensures that the respondent reacts consecutively to two instructions namely, (a) the level of the expectation and (b) the importance of the expectation. This questionnaire was administered together with the Organisational Commitment Questionnaire to two population groups within the military environment. The Pearson Product Moment Correlation was calculated between the strength of the psychological contract and organisational commitment and the significance of the correlations was evaluated.
\end{abstract}

\section{OPSOMMING}

Die doel van die studie is om ' $n$ meetinstrument met aanvaarbare metriese eienskappe vir die sterkte van die sielkundige kontrak vir Suid-Afrikaanse omstandighede te ontwerp en om empiries die verband tussen die sterkte van die sielkundige kontrak en organisasieverbondenheid te bepaal. Die sterkte van die sielkundige kontrak vraelys is op grond van die Dhammanungune-model ontwerp en het uit twee skale naamlik, die behoefteverwagting- en vervullingsverwagtingskale bestaan. Items vir elke skaal is sodanig geformuleer dat die respondent agteropeenvolgens op twee instruksies naamlik (a) die vlak van die verwagting en (b) die belangrikheid van die verwagting moet reageer. Dié vraelys is saam met die organisasieverbondenheidsvraelys op twee populasies uit 'n militêre omgewing toegepas. Die Pearson-produkmomentkorrelasie tussen die sterkte van die sielkundige kontrak en organisasieverbondenheid is bereken en die betekenisvolheid van die korrelasies is geëvalueer

Verskeie navorsingsartikels, besprekings by seminare en referate by kongresse is aan die sielkundige kontrak gewy (Littlefield, 1997, p.17). Hall (1996, p.8) som hierdie fokus op die sielkundige kontrak op met: 'while the popular writing on this topic has undoubtedly been overdone it is clear that in the next century (it) will be simply part of everyday work life. Die toenemende klem op die rol wat die sielkundige kontrak in die beroepswêreld speel en die wyse waarop dit gedragsuitkomste beïnvloed, noodsaak heelwat meer empiriese navorsing.

Die kontemporêre omgewing waarin veral Suid-Afrikaanse organisasies hul bevind, kan allermins as stabiel beskou word. Slabbert (1998) beskryf die veranderinge in die Suid-Afrikaanse besigheidsomgewing as radikaal, verreikend en meesleurend. Hierdie uitdagings wat aan Suid-Afrika gestel word, word veral deur die "World Competitiveness Report: 1997", wat die RSA vyf-en-veertigste op die ranglys van ses-en-veertig lande plaas, uitgelig. Die verslag beklemtoon dat produktiwiteit, winsmaking en daarmee saam langtermynoorlewing die belangrikste begrippe in die markgerigte ekonomieë van die wêreld geword het (IMD, 1997). Gedurende 1997 het 'n opname onder hoofuitvoerende beamptes tien strategiese kwessies wat SuidAfrikaanse besighede in die gesig staar, geïdentifiseer (Business Day, 1997, p.3). Die strategiese kwessies bevestig dat hoofuitvoerende beamptes van Suid-Afrikaanse organisasies die noodsaaklikheid daarvan erken om hulself in die toenemend kompeterende globale konteks te posisioneer, en die belangrikheid wat diensverhoudinge in die proses speel, besef.

Die sielkundige kontrak verskaf 'n model en teorie wat die begrip aangaande die verhouding tussen die werknemer en die werkgewer uit ' $n$ breër perspektief verklaar, met die klem op die elemente en die dinamika van wedersydse verwagtings. Rousseau \& Wade-Banzoni (1994) is in die opsig van mening

Requests for reprints should be addressed to K.J. Stanz, Dept. of Human Resource Management, RAU, PO Box 524, Auckland Park, 2006 dat die sielkundige kontrak nie net diensverhoudinge reguleer nie, maar ook in stand hou. Hierdie mening word ook deur skrywers soos Slabbert (1998) en Veldsman (1996) onderskryf.

Nou verwant hieraan is die feit dat enige kontrak 'n sekere mate van verbondenheid vereis van die partye wat daarby betrokke is. In die lig van bogenoemde uiteensetting van die belangrikheid van die sielkundige kontrak, het die vraag ontstaan of daar 'n verwantskap tussen die sielkundige kontrak en organisasieverbondenheid bestaan.

Ten einde die navorsing in perspektief te stel, is dit nodig om die sielkundige kontrak en organisasieverbondenheid van nader te ondersoek.

\section{Die Sielkundige Kontrak}

Die oorsprong van die sielkundige kontrak dateer uit die vroeë 1960's toe skrywers soos Argyris (1960), Levinson (1962) en Schein (1965) die term gebruik het om die werkgewerwerknemer verhouding te beskryf. Sedertdien het ' $n$ magdom navorsingsartikels, besprekings op seminare en referate by kongresse oor hierdie onderwerp die lig gesien (Baker, Spier \& Dhammanungune, 1989; Beukes \& Vos 1996; Dhammanungune, 1990; Guzzo \& Noonan, 1994; Hallier \& James, 1996; Lusero \& Allen, 1994; Robinson \& Morrison, 1995; Robinson, 1996; Robinson, Kraatz \& Rousseau, 1994; Robinson \& Rousseau, 1994; Rousseau, 1989; Rousseau, 1996; Rousseau \& Parks, 1993; Myburg \& Slabbert, 1998; Veldsman, 1996). Dit is geen verrassing dat verskeie definisies uit elke moontlike invalshoek vir die sielkundige kontrak bestaan nie.

Baker (1985, p.37; asook Baker et al., 1989) definieer die sielkundige kontrak as die somtotaal van alle geskrewe en ongeskrewe, gesproke en ongesproke verwagtings van die werknemer en die werkgewer. 


\section{FIGUUR 1: DIE KONTINUUM VAN DIE SIELKUNDIGE KONTRAK}

(Dhammanungune, 1990, p. 123)

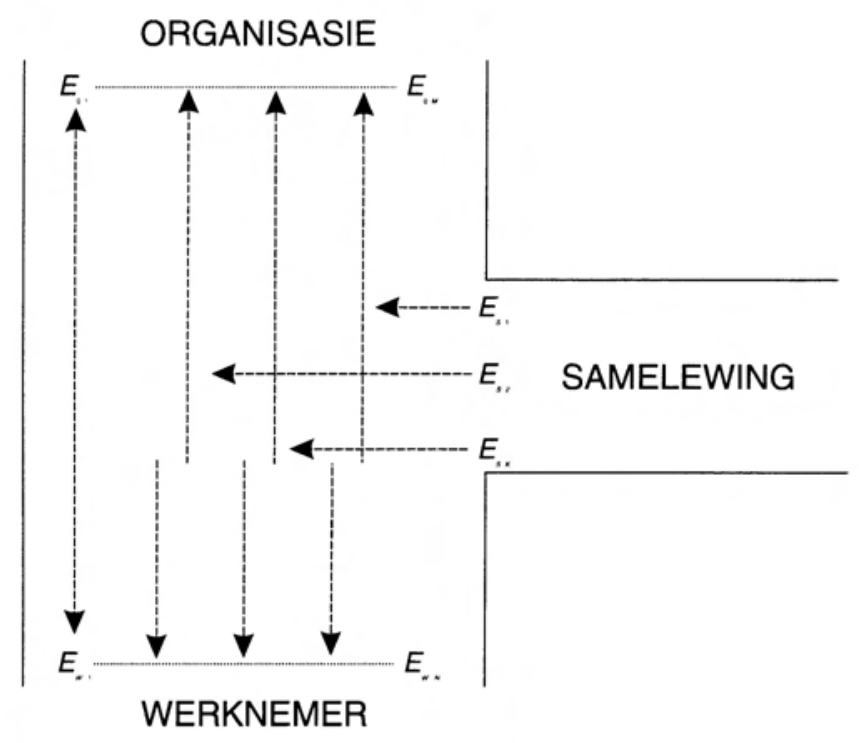

Dhammanungune (1990, p.152) gaan verder en definieer die sielkundige kontrak as die somtotaal van die eksplisiete en implisiete ooreenkomste ter vervulling van die werknemer en die organisasie se wedersydse verwagtings.

Rousseau (1989; en Rousseau \& Parks, 1993) definieer die sielkundige kontrak as die "individually held beliefs about the terms of the exchange between employer and employee".

In die navorsing is verskeie teoretiese modelle van die sielkundige kontrak ondersoek. Al hierdie modelle het die sielkundige kontrak as ' $n$ baie komplekse en dinamiese konstruk uitgebeeld. Verskillende navorsers het in 'n mindere of meerdere mate die metriese eienskappe van die sielkundige kontrak aangedui. Daar is vir die doel van hierdie studie op Dhammanungune se model van die sielkundige kontrak besluit omdat dié model die enigste is wat 'n basis voorsien om die sterkte van die sielkundige kontrak te operasionaliseer en wat voorsiening maak vir die interaksie tussen die werkgewer, die werknemer en die gemeenskap. Beukes (1994) en Beukes en Vos (1996, p.32) versterk die keuse met die bevinding dat die model die mees omvattendste model vir die sielkundige kontrak is en dat die enigste leemte die afwesigheid van 'n meetinstrument is.

Die Dhammanungune-model is gedurende 1990 onder leiding van Spier, Baker, Core en Thorp daargestel (Dhammanungune, 1990, p.1). Volgens Dhammanungune (1990) kom werknemer en organisasie met mekaar in kontak vir die wedersydse vervulling van hul dinamiese verwagtings. Die dinamiese aard van verwagtings word juis beklemtoon vanweë die feit dat verwagtings nie staties is nie en gereeld verander. Die sielkundige kontrak ontstaan vanuit die eksplisiete en implisiete ooreenkomste tussen werkgewer en werknemer om wedersydse verwagtings te vervul en daarom bepaal dit te alle tye elkeen se verwantskap en gedrag. Om die kompleksiteit van die sielkundige kontrak te illustreer, ontwikkel Dhammanungune (1990) 'n kontinuum van die sielkundige kontrak.

Figuur 1 toon dat die organisasie en individu mekaar se verwagtings wedersyds beïnvloed. (E01 - EOM : EWI - EWN)). Hierdie verwagtings word gekompliseer deur invloede en faktore uit die samelewing (FSI - FSK). Die pyltjies illustreer dat die kontrak dinamies is en voortdurend verander.

Uit die voorafgaande is dit duidelik dat die sielkundige kontrak uit vyf komponente bestaan: (a) die werknemer; (b) die organisasie; (c) 'n stel wedersydse verwagtinge; (d) 'n stel faktore uit die gemeenskap en (e) 'n kontinuum van tyd. Dhammanungune (1990 p. 115) vat dit soos volg saam:

"An employee links to an organisation by a set of the mutual expectations which is influenced by a set of factors in the societal environment; this phenomenon changes through a continuum of time"

Tydens enige gegewe tydstip van indiensneming probeer die individu en organisasie 'n passing tussen hul wedersydse verwagtings vind. Deur middel van kontraktuele onderhandeling, wat implisiete en eksplisiete ooreenkomste insluit, word die sielkundige kontrak gevorm. Figuur 2 illustreer diagrammaties hoe die kontraktuele onderhandelingsproses verloop.

Uit die model is dit duidelik dat ' $n$ passing in wedersydse verwagtings vir die individu tot positiewe gedrag soos motivering, verbondenheid, lojaliteit en tevredenheid kan lei. Die organisasie, in reaksie daarop, kan aan die individu vertroue, belonings, bevordering en goeie wedersydse betrekkings bied. As die individu of organisasie of beide partye agterkom dat daar inkongruensie in terme van verwagtinge bestaan, kan dit resulteer in kontrakverbreking en lei tot negatiewe uitkomste soos ontevredenheid, 'n realiteitskok, werkafwesigheid, traagheid en stres. Sodra die organisasie (bestuur) agterkom dat genoemde probleme wel bestaan, kan berading, teregwysing, waarskuwings of selfs afdanking gebruik word om die geskil te besleg. Uit die werknemer se oogpunt kan hierdie negatiewe uitkomste selfs tot afwykende gedrag soos sabotasie, weerwraak, frustrasie, neuroses en uiteindelike diensbeëindiging lei; dit is tensy die kontrak nie heronderhandel kan word nie. Figuur 2 toon duidelik dat die kontrak nooit staties is nie en enige tyd kan verander.

As gevolg van die wedersydse vervullingsgeneigdheid is die werknemer en die organisasie interafhanklik van mekaar. Anders gestel is die werknemer en die organisasie tot mekaar gebind. Die verhouding kan dus as ' $n$ band tussen die twee partye beskou word. Hieruit volg dit dat die sielkundige kontrak ' $n$ element van ' $n$ bindende krag het. Hierdie bindende krag tussen die organisasie en werknemer kan in terme van the overall degree of agreement to fulfill each other' gemeet word (Dhammanungune, 1990, p.117). Ten einde die vlak van die bindende krag te meet, formuleer Dhammanungune die vergelyking vir die Sterkte van die Sielkundige Kontrak (SSK) soos volg:

Die sterkte van die sielkundige kontrak is die vlak van die bindende krag tussen ' $n$ individu en ' $n$ organisasie wat ' $n$ funksie is van die algehele graad van ooreenkoms ter vervulling van wedersydse verwagtinge (Dhammanungune, 1990, p.117).

Wiskundig kan die SSK soos volg uitgedruk word: n

SSK $=f[1 /(\{\mid$ (Nei $x$ Wni) $-($ Fei $x$ Wfi $) \mid\}]$ $\mathrm{i}=1$

waar SSK = Sterkte van die sielkundige kontrak

$\mathrm{Ne}=$ Vlak van behoefteverwagting

$\mathrm{Fe}=$ Vlak van vervullingsverwagting

$\mathrm{Wn}=$ Gewig van behoefteverwagting

$\mathrm{Wf}=$ Gewig van vervullingsverwagting

$\mathrm{n}=$ Getal elemente van verwagting

Hierdie vergelyking bring ' $n$ totaal nuwe dimensie in die meting van die sielkundige kontrak as konstruk mee. 'n Vraelys kan op grond van die vergelyking saamgestel word. As ' $n$ element van 'n verwagting geneem word, is dit moontlik om 'n behoefteverwagting en vervullingsverwagting te formuleer. Vir elkeen van hierdie verwagtings kan daar 'n vlak en gewig van die verwagting geformuleer word. Dit sal beteken dat daar vir elke behoefte- en vervullingsverwagtingselement 'n vlak- en gewigsdimensie is. Hieruit volg dit dat daar inderwaarheid vier 
FIGUUR 2: DIE VOORSPELLINGSMODEL VAN DIE SIELKUNDIGE KONTRAK

(Dhammanungune, 1990, p. 163)

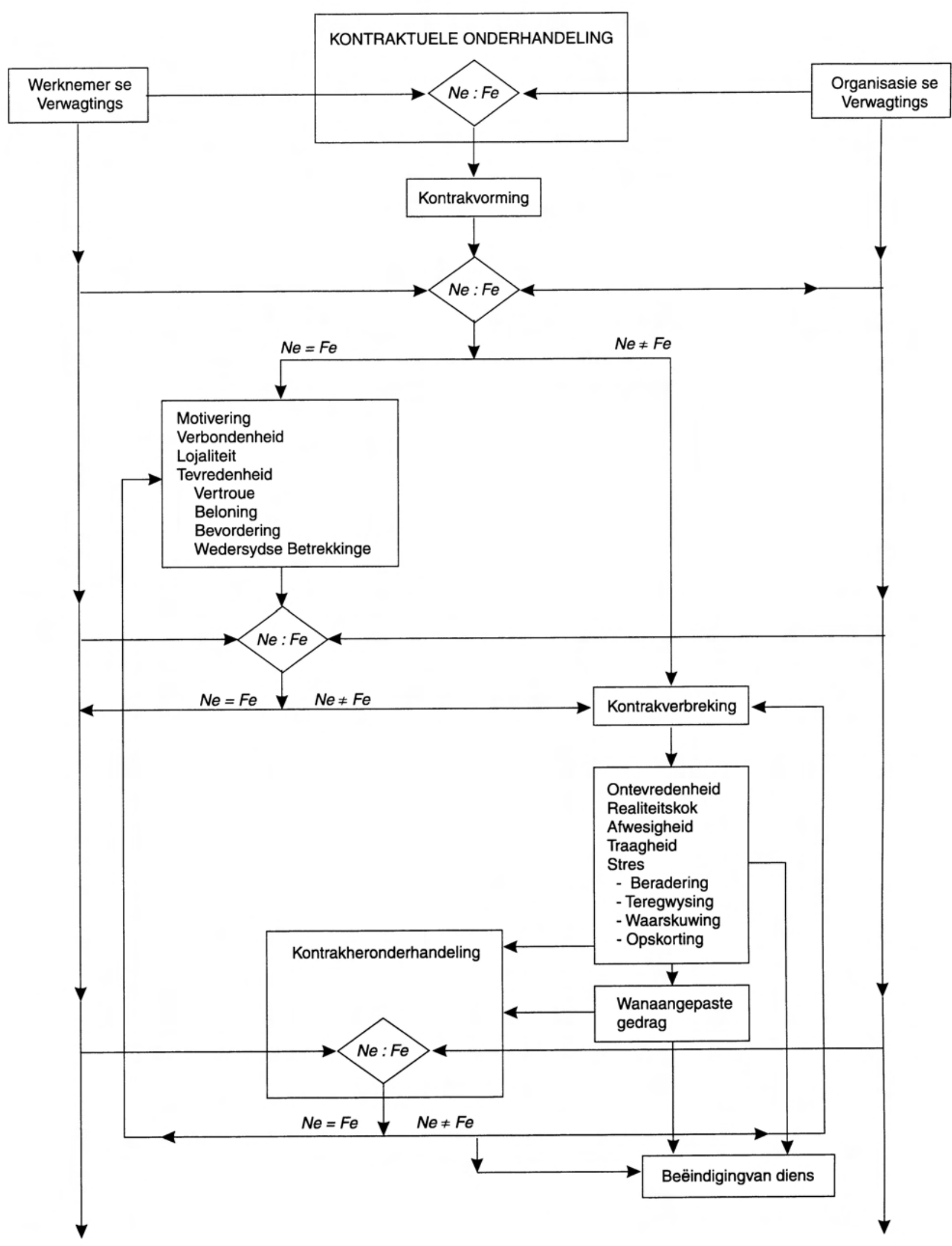

$\mathrm{NE}=$ Behoeftes en verwagtings van die individu

$\mathrm{FE}=$ Verwagting dat behoeftes vervul kan word 
subskale in 'n vraelys vir die sterkte van die sielkundige kontrak behoort te wees.

\section{Organisasieverbondenheid}

Net soos in die geval van die sielkundige kontrak bestaan daar verskeie definisies vir organisasieverbondenheid. Aanvanklik is daar gedebatteer of verbondenheid 'n houding of gedragsverskynsel is (Allen \& Meyer, 1990; Mowday, Porter \& Steers, 1982). Dit blyk uit die literatuur dat die konstruk multidimensioneel van aard is. Konsensus is egter nog nie bereik oor wat hierdie dimensies is, of hoe dit kombineer om verbondenheid te vorm nie (Kamfer, Venter \& Boshoff, 1994).

Mowday et al. (1982) definieer organisasieverbondenheid as die relatiewe sterkte van 'n individu se identifikasie met en betrokkenheid by 'n organisasie. Konseptueel kan organisasieverbondenheid aan drie eienskappe uitgeken word: (a) 'n sterk geloof in en die aanvaarding van die organisasie se doelwitte en waardes; (b) 'n bereidwilligheid om noemenswaardige pogings namens die organisasie uit te oefen; en (c) 'n sterk begeerte om lidmaatskap van die organisasie te behou (Mowday et al., 1982). Mowday et al. bevind dat daar 'n sentrale tema naamlik, 'n vorm van uitruiling, regdeur die konsepsuele werk oor organisasieverbondenheid gevind word. 'Individuals come to organisations with certain needs, desires, skills, and so forth, and expect to find a work environment where they can use their abilities and satisfy many of their basic needs' (Mowday et al., 1982, p. 27).

Dit wil voorkom of dit juis hierdie sentrale tema van uitruilbaarheid is wat tot ' $n$ groot verskeidenheid navorsing oor die verhouding tussen organisasieverbondenheid en verskeie gehipotetiseerde gevolge van organisasieverbondenheid aanleiding gegee het. Mathieu \& Zajac (1990) gee 'n gedetailleerde samevatting van navorsing wat oor organisasieverbondenheid gedoen is. Uit die skrywers se navorsing blyk dit duidelik dat organisasieverbondenheid 'n groot aantal navorsingsresultate opgelewer het. Verskeie modelle en meetinstrumente is met verloop van tyd ontwikkel (Kamfer et al., 1994). Uit die literatuur blyk dit egter dat die bekendste en algemeenste in gebruik, bekend staan as "the approach to organisational commitment ... (with) the Organisational Commitment Questionaire" (OCQ) en deur Porter en Smith in 1970 ontwikkel is (Mowday, Steers \& Porter, 1979).

Alhoewel Suid-Afrikaanse studies oor organisasieverbondenheid skaars blyk te wees, het enkele publikasies wel die afgelope paar jaar die lig gesien (Boshoff, Bester, Bennett \& Heyl, 1992; Cooke \& Basson, 1992; Roodt, 1992; Kamfer et al., 1994).

Uit die literatuur is dit duidelik dat die sielkundige kontrak verskeie gevolge en uitkomste vir sowel die individu as die organisasie inhou. Dhammanungune (1990 p.188) som dit in sy teorie oor die sielkundige kontrak soos volg op "... it determines every employment relationship and behaviour at all times". Navorsing deur Kotter (1970) Rousseau \& WadeBanzoni (1994) bevestig hierdie siening. Hierdie mening word ook deur Suid-Afrikaanse skrywers soos Slabbert (1998) en Veldsman (1996) onderskryf. Organisasieverbondenheid is tradisioneel aanvaar as 'n faktor wat tot positiewe gedragsuitkomste aanleiding gee. Die konstruk word op sigself as 'n gedragsuitkoms aanvaar (Johnston \& Snizek, 1991).

Daar bestaan, sover vasgestel kon word, geen gepubliseerde navorsing oor die verwantskap tussen die sielkundige kontrak en organisasieverbondenheid nie. Verskeie navorsingstudies verwys egter na sekere gedragsuitkomste wat uit die sielkundige kontrak voortspruit en waar 'n verband met organisasieverbondenheid veronderstel of geïmpliseer word. Enkele sodanige verwysings wat in die konteks van die bespreking oor die sielkundige kontrak gemaak is, word vervolgens aangehaal:
"Their psychological contract with their employer and, ultimately their commitment to that employer" ( Guzzo \& Noonan, 1994, p. 447).

"The fulfilment of the psychological contract (influences employee loyalty and commitment" (Guzzo \& Noonan, 1994, p. 452$)$.

"Most employees have become less committed" (Hallier \& James, 1996, p.705).

"Not only is lower commitment likely to be an important casualty ... but a violation of the psychological contract can also occur" (Lusero \& Allen, 1994, p. 426).

"The combination of possible consequences following a perceived psychological contract violation, e.g., decrease in commitment ... urges any business organisation to take the concept of the psychological contract seriously" (Myburg \& Slabbert, 1998).

"It is associated with various negative outcomes such as a decrease and reduced commitment and satisfaction (Robinson, Kraatz \& Rousseau, 1994; Robinson \& Rousseau, 1994; Robinson \& Morrison, 1995; Robinson, 1996, p. 574)

"Is the creation of a contract that it is hoped engenders commitment" (Rousseau, 1996, p. 51). (Robinson, Kraatz \& Rousseau, 1994; Robinson \& Rousseau, 1994; Robinson \& Morrison, 1995; Robinson, 1996, p. 574).

Uit die voorafgaande blyk dit dat sielkundige kontrak en organisasieverbondenheid ' $n$ onderlinge verband tot mekaar kan hê. Met die afwesigheid van gepubliseerde navorsing kan die model van die sterkte van die sielkundige kontrak wat deur Dhummanungune daar gestel word hierdie oënskynlike leemte om die verband empiries te ondersoek, oorbrug.

\section{Probleemstelling}

Op grond van die voorafgaande teoretiese ontleding en met inagneming van die formulering van die motivering vir die studie, kan die probleemstelling soos volg gestel word: Wat is die sterkte van die sielkundige kontrak en hoe vergelyk die sterkte van die sielkundige kontrak van 'n persoon met ' $n$ hoë organisasieverbondenheid met die van 'n persoon met ' $n$ lae organisasieverbondenheid?

Die doel van hierdie studie is:

Om 'n meetinstrument met aanvaarbare metriese eienskappe vir die sterkte van die sielkundige kontrak vir Suid-Afrikaanse omstandighede te ontwerp.

Om empiries die verband tussen die sterkte van die sielkundige kontrak en organisasieverbondenheid te bepaal.

$\mathrm{Na}$ aanleiding van die literatuurstudie, die probleemstelling en die doelstelling van die studie, word die volgende hipotese gestel:

Hipotese 1: Daar is ' $n$ statisties beduidende verband tussen die sterkte van die sielkundige kontrak en organisasieverbondenheid.

\section{METODE}

Die metode wat in die studie gevolg is, word vervolgens onder die hoofde steekproef, meetinstrumente en prosedure bespreek.

\section{Die Steekproef}

Die proefpersone vir hierdie studie is lede van die SANW en 
meer spesifiek die SA Leër. Daar is van twee populasies gebruik gemaak. Die eerste populasie bestaan uit die totale populasie Afrikaanssprekende manlike toetreders tot junior bestuursposte in die Suid-Afrikaanse Leër (algemeen bekend as Junior Leiers en wat, sodra hul hul opleiding voltooi, as onderoffisiere en offisiere in die SA Leër aangestel sal word). Die populasie staan as die werknemers in die studie bekend. Die ouderdom van die aanvanklike 230 respondente wissel tussen 19 en 22 en het reeds hul eerste ses maande militêre opleiding voltooi.

Die tweede populasie bestaan uit die nege topbestuurslede van die Suid-Afrikaanse Leër in sowel lyn- as stafindelings. Die populasie verteenwoordig die werkgewer in die studie. Die populasie van nege lede bestaan uit beide mans en dames tussen die ouderdom 44 en 53 met tussen 20 tot 30 jaar diens in die SA Leër.

As gevolg van die omvang van die populasies word die populasies in hul geheel gebruik.

\section{Meetinstrumente}

Die twee instrumente naamlik, die Sterkte van die Sielkundige Kontrak Vraelys en die Organisasieverbondenheidsvraelys, sal vervolgens in meer besonderhede bespreek word.

\section{Sterkte van die Sielkundige Kontrak Vraelys (SSKV).}

In die teoretiese fundering is daarop gewys dat verskillende navorsers in mindere of meerdere mate die metriese eienskappe van die sielkundige kontrak kan aandui. Uit die navorsingsbevindinge kristalliseer 'n geheelbeeld van die sielkundige kontrak as synde ' $n$ veelfasettige, komplekse psigologiese konstruk, bestaande uit ' $n$ aantal teoreties onderskeibare dimensies. Daar bestaan egter sover bepaal kan word geen meetinstrument wat die sterkte van die sielkundige kontrak meet nie. Die sterkte van die sielkundige kontrak is gedefinieer as die vlak van die bindende krag tussen ' $n$ individu en die organisasie. Dit is ' $n$ funksie van die algehele graad van instemming om wedersydse behoeftes te bevredig. Hiervolgens is die vraelys vir die sterkte van die sielkundige kontrak met twee komplementerende skale opgestel naamlik die behoefteverwagtingskaal en die vervullingsverwagtingskaal. Die items vir die skale is sodanig geformuleer dat die respondent op twee instruksies agtereenvolgens moet reageer naamlik, (a) vlak van verwagting, en (b) hoe belangrik dit is om die vlak van verwagting te bevredig of anders gestel die gewig van die vlak van verwagting. Elk van hierdie instruksies vorm 'n subskaal in die vraelys. Dit beteken dat die SSKV uit twee skale bestaan en wat op hul beurt weer uit twee subskale saamgestel is. Effektief beteken dit dat die SSKV vier subskale het. Die behoefteverwagtingskaal omvat verwagtings gekoester rondom wat die respondente hoop om te kry, te ontvang, of te baat. Die skaal bestaan uit 38 items waarop die respondent agteropeenvolgens op twee instruksies reageer. Die vervullingsverwagtingskaal omvat verwagtings gekoester rondom wat respondente hoop om te gee, by te dra, of te doen. Die skaal bestaan uit 27 items waarop die respondent agteropeenvolgens op twee instruksies reageer.

\section{Die Organisasieverbondenheidsvraelys (OCQ).}

In die afwesigheid van konsensus oor die multidimensionele aard van organisasieverbondenheid, is vir die doeleindes van die studie besluit om die 16 item OCQ van Porter et al., (1970) te gebruik. Die rede hiervoor is dat die metriese eienskappe van die vraelys in verskeie studies bevestig is. Mowday et al., (1982) rapporteer betroubaarheidskoëffisiente van tussen 0,82 en 0,93 op verskillende steekproewe. Alhoewel die OCQ nie vir Suid-Afrikaanse toestande gestandaardiseer is nie, is die metriese eienskappe in ' $n$ bevestigende faktorontleding wat deur Kamfer et al., (1994) onder Suid-Afrikaanse omstandighede uitgevoer is, wel bevestig. Kamfer et al. rapporteer ' $n$ betroubaarheidskoëffisient van 0,89.

\section{Prosedure}

Aan die hand van die literatuuroorsig en spesifiek die teorie van Dhammanungune oor die sielkundige kontrak, is items geformuleer vir insluiting in 'n voorlopige vraelys oor die sterkte van die sielkundige kontrak. Die vraelys is aan 'n groep bedryfsielkunde-interns en daarna aan spesialiste in die veld, asook aan 'n taalkundige voorgelê. Kommentaar oor sterk- en swakpunte is verkry en sodoende is tekortkominge geïdentifiseer en is daar gepoog om die vraelys te verbeter. Die voorlopige vraelys is in ' $n$ voorondersoek deur 'n groep proefpersone voltooi om hul kommentaar rondom sterk- en swakpunte, taalprobleme, onduidelikhede en logistieke reëlings te verkry. Verskeie tekortkominge is geïdentifiseer en regstellings is gedoen.

Nadat toestemming verkry is, is die SSKV en OCQ op die steekproewe (werknemers en werkgewers) toegepas. Deelname aan die projek was nie verpligtend nie, maar vanweë die besondere aard van 'n militêre opleidingsinstansie het 211 (van die 230) werknemers en 9 werkgewers vir toetsing aangemeld. Die prosedure vir die afneem van die vraelyste was vir albei steekproewe dieselfde. Die vraelyste is deur die navorser persoonlik afgeneem. Genoeg tyd is toegelaat sodat alle respondente die vraelyste gemaklik kon voltooi

Indien enige item onvoltooid gelaat is, is die vraelys nie geskik vir verwerking geag nie. Die data is direk vanaf die vraelyste in ASCI-formaat op die rekenaar ingevoer. Daarna is alle statistiese verwerkings deur die Statistiese Konsultasiediens van die Randse Afrikaanse Universiteit, rekenaarmatig met behulp van die SPSS Windows-pakket uitgevoer. Die prosedure wat met die itemontledings gevolg is, is op Gulliksen (1950) se benadering gebaseer. Die NP50-program van die Nasionale Instituut vir Personeelnavorsing is daarvoor gebruik.

\section{RESULTATE}

Die resultate van elke meetinstrument word vervolgens in meer besonderhede bespreek. Let daarop dat elke skaal aan 'n afsonderlike faktor- en itemontleding onderwerp is.

\section{Sterkte van die Sielkundige Kontrak Vraelys (SSKV)}

Ten einde die bespreking te vereenvoudig, word die resultate van die behoefteverwagtingskaal en vervullingsverwagtingskaal in terme van hul onderskeie subskale beskou.

\section{Vlak van behoefteverwagting (Subskaal 1A)}

Dié items is geïnterkorreleer, en die eigenwaardes van die interkorrelasiematriks is bereken. Daar is soveel faktore gepostuleer as wat daar eigenwaardes groter as een was (Kaiser, 1961). Vervolgens is die interkorrelasiematriks aan 'n eerste-faktorontleding onderwerp. Die verkreë faktormatriks is na 'n eenvoudige struktuur geroteer met behulp van die varimaksrotasie. Die eerste-faktorontleding is slegs gebruik om die items te groepeer in ' $n$ aantal subtoetse. Vervolgens is die subtoetse geïnterkorreleer en aan 'n tweede-faktorontleding onderwerp (Schepers, 1992). Kaiser (1961) se kriterium is weereens gebruik om te besluit oor die getal faktore. Die verkreë faktormatrikse is na 'n eenvoudige struktuur geroteer met behulp van die "Direct Oblimin" rotasie.

Met die eerste-faktorontleding is 11 faktore onttrek. ' $n$ Tweedefaktorontleding is op die 11 subtoetse uitgevoer, en vier faktore is verkry. Die interkorrelasiematriks $(38 \times 38)$ is te groot om in die artikel te rapporteer. Die interkorrelasies van die geroteerde faktore het getoon dat die faktore laag met mekaar korreleer en dus onafhanklike subtoetse vorm. Subtoets 1 hou verband met geldelike en ekonomiese verwagtings wat gekoester word. Subtoets 2 hou verband met aanvaarding van die self, deur familie en die gemeenskap. Subtoets 3 hou verband met mens 
TABEL 1

GEMIDDELDE ITEMSTATISTIEKE VAN DIE BEHOEFTEVERWAGTINGSKALE

VLAK VAN BEHOEFTEVERWAGTING (SUBSKAAL 1A)

\begin{tabular}{|c|c|c|c|c|c|c|}
\hline Subtoets & Items & $\alpha$ & $r_{x g} S_{g}$ & $r_{x g}$ & $\mathrm{~S}_{\mathrm{g}}$ & $\operatorname{Max} \propto 12$ \\
\hline Subtoets 1 & 14 & 0,817 & 0,746 & 0,542 & 1,360 & $\begin{array}{c}0,817 \\
(14 \text { items })\end{array}$ \\
\hline Subtoets 2 & 14 & 0,876 & 0,938 & 0,612 & 1,504 & $\begin{array}{c}0,881 \\
(8 \text { items })\end{array}$ \\
\hline Subtoets 3 & 9 & 0,685 & 0,659 & 0,536 & 1,230 & $\begin{array}{c}0,685 \\
(9 \text { items })\end{array}$ \\
\hline
\end{tabular}

- $\mathrm{r}_{\mathrm{xg}} \mathrm{S}_{\mathrm{g}}-$ Gemiddelde van die indekse van betroubaarheid van die items

- $\mathrm{r}_{\mathrm{xg}}$ - Gemiddelde van die punttweedeling korrelasies van die items met die totaaltelling

- $\mathrm{S}_{\mathrm{g}}$ - Die gemiddelde van die standaardafwykings van die items

- $\quad \alpha$ - Betroubaarheid volgens Cronbach se koëffisiënt alfa

- Max $\alpha$ - Betroubaarheid volgens Cronbach se koëffisiënt alfa nadat items uitgelaat is

TABEL 2

GEMIDDELDE ITEMSTATISTIEKE VAN DIE BEHOEFTEVERWAGTINGSKAAL:

BELANGRIKHEID VAN DIE VLAK VAN

BEHOEFTEVERWAGTING (SUBSKAAL 1B)

\begin{tabular}{rcccccc}
\hline Faktor & Items & $\alpha$ & $\mathrm{r}_{\mathrm{xg}} \mathrm{S}_{\mathrm{g}}$ & $\mathrm{r}_{\mathrm{xg}}$ & $\mathrm{S}_{\mathrm{g}}$ & $\operatorname{Max} \alpha$ \\
Subtoets 1 & 38 & 0,942 & 0,680 & 0,565 & 1,204 & 0,942 \\
& & & & & & $(38$ items $)$
\end{tabular}

TABEL 3

GEMIDDELDE ITEMSTATISTIEKE VAN DIE

VERVULLINGSVERWAGTINGSKAAL: VLAK VAN VERVULLINGSVERWAGTING (SUBSKAAL 2A)

\begin{tabular}{rcccccc}
\hline Faktor & Items & $\alpha$ & $\mathrm{r}_{\mathrm{xg}} \mathrm{S}_{\mathrm{g}}$ & $\mathrm{r}_{\mathrm{xg}}$ & $\mathrm{S}_{\mathrm{g}}$ & $\operatorname{Max} \alpha$ \\
Subtoets 1 & 27 & 0,917 & 0,651 & 0,566 & 1,150 & 0,920 \\
& & & & & & $(26$ items $)$
\end{tabular}

TABEL 4

GEMIDDELDE ITEMSTATISTIEKE VAN DIE VERVULLINGSVERWAGTINGSKAAL: BELANGRIKHEID VAN DIE VLAK VAN VERVULLINGSVERWAGTING (SUBSKAAL 2B)

\begin{tabular}{rcccccc}
\hline Faktor & Items & $\alpha$ & $\mathrm{r}_{\mathrm{xg}} \mathrm{S}_{\mathrm{g}}$ & $\mathrm{r}_{\mathrm{xg}}$ & $\mathrm{S}_{\mathrm{g}}$ & $\operatorname{Max} \alpha$ \\
Subtoets 1 & 27 & 0,953 & 0,787 & 0,669 & 1,171 & $\begin{array}{c}0,920 \\
(26 \text { items })\end{array}$
\end{tabular}

TABEL 5

GEMIDDELDE ITEMSTATISTIEKE VAN DIE ORGANISASIEVERBONDENHEIDSVRAELYS

\begin{tabular}{rcccccc}
\hline Faktor & Items & $\alpha$ & $\mathrm{r}_{\mathrm{xg}} \mathrm{S}_{\mathrm{g}}$ & $\mathrm{r}_{\mathrm{xg}}$ & $\mathrm{S}_{\mathrm{g}}$ & $\operatorname{Max} \alpha$ \\
Subtoets 1 & 15 & 0,752 & 0,974 & 0,541 & 1,624 & $\begin{array}{c}0,758 \\
\text { (13 items) }\end{array}$
\end{tabular}

en organisatoriese passingsattribute. Subtoets 4 het net een item, maar dit is insiggewend dat die item oor die vlak van voorkeurbehandeling in die organisasie handel. Dit wil voorkom of die feit dat toekomstige aanstellings in die SA Leër op 'n kwotastelsel gebaseer gaan word, voorkeurbehandeling sodanig ervaar word dat dié item alleen op 'n faktor laai. Die drie faktore stem met Dhammanungune (1990) se teorie oor die sielkundige kontrak ooreen.

Ten einde die indekse van betroubaarheid van die subtoetse te bepaal, is die items met hoë ladings binne elke subtoets aan 'n itemontleding onderwerp. 'n Opsomming van die bevindings word in Tabel 1 gerapporteer. Die betroubaarheidskoëffisiënte van die drie faktore is hoogs aanneemlik. Daar is besluit om ter wille van geldigheid al die items van die drie subtoetse te behou. Faktor 4 het slegs een item opgelewer en is weggelaat uit die ontleding. Die items van subtoets drie kan egter vir toekomstige gebruik uitgebrei word om die betroubaarheid te verhoog.

\section{Belangrikheid van die vlak van behoefteverwagting (Subskaal 1B).}

Dieselfde prosedure vir die verwerking van gegewens as vir subskaal IA is gevolg. Met die eerste-faktorontleding is nege faktore onttrek. 'n Tweede-faktorontleding is op die nege subtoetse uitgevoer, en een faktor is verkry. Al die items hou dus verband met die belangrikheid van die behoefteverwagting. Die itemontleding het ' $n$ betroubaarheidskoëffisiënt van 0,942 opgelewer wat hoogs aanneemlik is. Daar is besluit om ter wille van geldigheid al die items van die skaal te behou. ' $n$ Opsomming van die bevindings word in Tabel 2 gegee.

Vlak van vervullingsverwagting (Subskaal 2A). Dieselfde prosedure is weereens gevolg. Met die eerste-faktorontleding is vyf faktore onttrek. 'n Tweede-faktorontleding is op die vyf subtoetse uitgevoer, en een faktor is verkry. Die interkorrelasiematriks $(27 \times 27)$ is te groot om in die artikel te rapporteer. Die subtoets hou verband met verwagtings wat gekoester word rondom wat gehoop word om by te dra, te gee, of te doen. Die betroubaarheidskoëffisiënt van 0,917 vir die skaal is hoogs aanneemlik. Ter wille van geldigheid is al die items van die faktor behou. 'n Opsomming van die bevindings word in Tabel 3 gerapporteer.

Belangrikheid van die vlak van vervullingsverwagting (Subskaal 2B). Dieselfde prosedure is weereens gevolg. Met die eerstefaktorontleding is drie faktore onttrek. 'n Tweede-faktorontleding is op die drie subtoetse uitgevoer, en een tweede-faktor is verkry. Al die items hou dus verband met die belangrikheid van die vervullingsverwagting. Die betroubaarheidskoëffisiënt van 0,953 van die skaal is weereens hoogs aanneemlik. Ter wille van geldigheid is al die items van die skaal behou. 'n Opsomming van die bevindings word in Tabel 4 gerapporteer.

Vir elke respondent is 'n totaaltelling vir elk van die vier subskale bereken deur die itemtellings van die subskaal se subtoetse (waar van toepassing) in standaartformaat te sommeer. Die vier tellings wat hieruit voortgespruit het, is vervolgens in die formule van Dhammanungune (1990) gebruik om vir elke respondent ' $\mathrm{n}$ telling vir die SSK te verkry.

\section{Organisasieverbondenheidsvraelys}

Ofskoon daar reeds deur Kamfer et al. (1994)'n bevestigende faktorontleding gedoen is, is besluit om weereens ' $n$ faktorontleding te doen ten einde die struktuur te bevestig. Dieselfde prosedure soos in die geval van die SSKV, is vir die verwerking van die gegewens van die OCQ gebruik. Met die eerstefaktorontleding is vier faktore onttrek. ' $n$ Tweede-faktorontleding is op dié vier subtoetse uitgevoer, en een faktor is verkry. Hierdie enkele skaal van die OCQ het 'n betroubaarheidskoëffisiënt van 0,75 en is aanneemlik. Die betroubaarheidskoëffisiënt 
vergelyk goed met die van Mowday et al. (1982) van tussen 0,82 en 0,93 vir verskillende steekproewe, asook met die van Kamfer et al. (1994) van 0,89 wat onder Suid-Afrikaanse omstandighede gevind is. Ter wille van geldigheid is al die items van die skaal behou. 'n Opsomming van die bevindings word in Tabel 5 gerapporteer.

Vir elke respondent is ' $n$ totaaltelling vir die OCQ bereken deur die itemtellings in standaardformaat te sommeer.

Die resultate van die ondersoek na 'n verband tussen die Sterkte van die Sielkundige Kontrak en Organisasieverbondenheid sal vervolgens bespreek word. Die Pearson-produkmomentkorrelasie tussen die SSKV-telling en die afhanklike veranderlike, organisasieverbondenheid, is bereken. Met 'n korrelasie van 0,083 , ' $n$ betekenisvolheid (Tweekantig) van 0,253 is daar geen statistiese beduidende verband nie. Die resultate word in Tabel 6 gerapporteer.

TABEL 6

DIE PEARSON-PRODUKMOMENTKORRELASIE

\begin{tabular}{lcc} 
& OCQ & SSK \\
\hline OCQ & 1,00 & 0,083 \\
Betekenisvolheid & & 0,253 \\
(Tweekantig) & & \\
$\mathrm{N}$ & 193 & 193
\end{tabular}

\section{GEVOLGTREKKINGS EN AANBEVELINGS}

Die SSKV het aan alle verwagtings voldoen en bevestig weereens dat die tyd wat aan itemontwikkeling en itemformulering gespandeer word, vrugte afwerp. Die SSKV het aan al die metriese vereistes wat tydens die ontwikkeling gestel is, voldoen. Die items van subtoets 3 van subskaal $1 A$ (vlak van behoefteverwagting) kan egter vir toekomstige gebruik uitgebrei word om die betroubaarheid daarvan te verhoog.

Die faktor- en itemontleding op die OCQ het die struktuur van die vraelys weereens bevestig. Dié bevinding versterk die navorsing oor die metriese eienskappe wat deur die bevestigende faktorontleding van Kamfer et al., (1994) onder SuidAfrikaanse omstandighede verkry is.

Uit die resultate van hierdie ondersoek blyk dit dat die twee vraelyste oor bevredigende psigometriese eienskappe beskik. Alfa-koëffisiënte vir die SSKV is hoogs aanneemlik, terwyl dié van die OCQ aanneemlik is. Albei die meetinstrumente het dus aan die gestelde metriese vereiste voldoen.

$\mathrm{Na}$ aanleiding van die literatuurstudie, die probleemstelling en die doelstelling van die ondersoek was die fokus daarop gerig om 'n empiriese verband tussen die sielkundige kontrak en organisasieverbondenheid bloot te lê. Die Pearson-produkmomentkorrelasie het egter geen betekenisvolle verband tussen die twee konstrukte opgelewer nie. Die hipotese van 'n statisties beduidende verband tussen die sielkundige kontrak en organisasieverbondenheid word dus ten opsigte van hierdie steekproef verwerp.

Alhoewel verskeie studies die teoretiese aanname maak dat daar 'n verband tussen die sielkundige kontrak en organisasieverbondenheid is, of behoort te wees, steun die resultate van hierdie studie nie die aannames nie. Dit beteken ook dat die aanname wat Dhammanungune (1990) in sy teorie oor die sielkundige kontrak maak, naamlik dat die sterkte van die sielkundige kontrak 'n determinant van gedragsuitkomste is, nie in die huidige studie aanvaar kan word nie.
Sover vasgestel kan word, kan geen vorige navorsingsbevindinge lig op hierdie resultate werp nie. Dhammanungune (1990) beweer dat realiteitskok tot negatiewe houdings teenoor die organisasie, 'n afname in die begeerte om vir die organisasie te werk en verhoogde vlakke van afwesigheid en werksontevredenheid lei. Dean (1984) bevind wel dat realiteitskok ontstaan waar werknemers se verwagtings hoër was as dit wat hulle werklik in die organisasie ervaar het. 'n Realiteitskok is die verskil tussen ' $n$ individu se verwagting en sy belewenis van daardie uitkoms van die verwagtings. Dean (1984) bevind dat realiteitskok negatief korreleer met organisasieverbondenheid en verbondenheidsrelevante gedrag. Die vraag is egter of realiteitskok nie ook in die SSKV sou reflekteer nie.

Die studie het egter verskeie unieke sterkpunte. Dit het 'n meer gedetailleerde ontleding van die verband tussen die sielkundige kontrak en organisasieverbondenheid behels en sowel die werknemer as die werkgewer se sterkte van die sielkundige kontrakte is betrek. Tweedens het die studie op empiriese navorsing berus, terwyl vorige studies op teoretiese aannames berus het.

Daar is egter ook beperkings in die studie. Die SANW bevind hom tans te midde van ' $n$ transformasieproses en is dit moeilik om die impak daarvan te isoleer. Die relatief klein steekproef kon moontlik die ontleding beperk. Die steekproef is nie ten volle verteenwoordigend nie en kan verder uitgebrei word om ook taal, ras en geslag in te sluit. Die veralgemening van die resultate behoort net tot Afrikaanssprekende mans in die SA Leër beperk te word. Die aspekte behoort in 'n opvolgstudie aangespreek te word.

\section{ERKENNINGS}

Opregte dank aan Elsebe Smit vir haar hulp met die statistiese ontledings.

\section{SYNOPSIS}

As far as can be determined no published research exists concerning the relationship between the psychological contract and organisational commitment. Various research studies, however, refer to certain behavioural outcomes that stem from the psychological contract and where a link to organisational commitment is presumed or implied.

The aim of this study is to design a measuring instrument with acceptable metric characteristics for the strength of the psychological contract within the South African context, and to determine empirically the relation between the strength of the psychological contract and organisational commitment.

The Dhammanungune Model served as foundation for the design of the Strength of the Psychological Contract Questionnaire (SPCQ) which consists of two scales namely, a need expectation scale and a fulfilment expectation scale. The items of each scale have been formulated in the manner that ensures that the respondent reacts consecutively to two instructions namely, (a) the level of the expectation and (b) the importance of the expectation.

This questionnaire was administered together with the Organisational Commitment Questionnaire (OCQ) to two population groups within the military environment.

A factor analysis was carried out on the SPCQ and OCQ to ascertain the dimensionality of the vectorspace of test items. To address the problem of artefactors a second factor analysis was done on the intercorrelated sub scores of the first factor analysis. After the true factors was identified a separate item analysis was done for each second factor. The item analysis ensured that items with low indices of reliability were excluded. 
The reliability of measures was also assessed by the item analysis according to Cronbach's coefficient alpha. The item analysis was performed by using the NP50 programme.

The results for the SPCQ are as follow:

The level of need expectation (subscale 1A) produced four factors (subtests) but the fourth factor, with only one item was disregarded. The reliability according to Cronbach's coefficient alpha for subtest one $(0,817)$ and subtest two $(0,876)$ are highly acceptable, for subtest three $(0,685)$ it is recommended that the items be increased for feature use.

The importance of the need expectation (subscale $1 \mathrm{~B}$ ) produced one factor (subtest). The reliability according to Cronbach's coefficient alpha for this subtest $(0,942)$ is highly acceptable.

The level of fulfilment expectation (subscale 2A) produced one factor (subtest). The reliability according to Cronbach's coefficient alpha for this subtest $(0,917)$ is highly acceptable.

The importance of need expectation (subscale 2B) produced one factor (subtest). The reliability according to Cronbach's coefficient alpha for this subtest $(0,953)$ is highly acceptable.

The result for the OCQ is as follows:

The OCQ produced one factor (subtest). The reliability according to Cronbach's coefficient alpha for this subtest $(0,75)$ is highly acceptable.

The scores for each questionnaire were standard-formatted, summated and the Pearson Product Moment Correlation was calculated between the strength of the psychological contract and organisational commitment and the significance of the correlation were evaluated.

No significant correlation $(0,083)$ was found between the strength of the psychological contract and organisational commitment. The assumption by Dhammanungune (1990) in his theory on the psychological contract, that the strength of the psychological contract determines behavioural outcomes, could not be proved in this study.

\section{VERWYSINGS}

Allen, N.J. \& Meyer, J.P. (1990). The measurement and antecedents of affective continuance and normative commitment to the organisation. Journal of Occupational Psychology, 63(1), 1-18.

Argyris, C. (1960). Understanding organisational behaviour. Homewood, Illinois: Dorsey.

Baker, H.G. (1985). The unwritten contract: Job perceptions. Personnel Journal, 64(9), 36-41.

Baker, H.G. (1985). Psychological contract: Clarifying applicant and organisational expectations in military recruiting. San Diego, CA: Navy Personnel Research and Development Centre.

Baker, H.G., Spier, M.S., \& Dhammanungune, S. (1989). Trust, credibility, and empowerment: The psychological contract at work. Paper presented at the Organisation Development Network National Conference, San Diego, CA.

Boshoff, A.B., Bester, D.C., Bennett, H.F. \& Heyl, G.L. (1992). Career orientation and organisational commitment of engineers in managerial and specialist career paths an exploratory study. Paper presented at the 10th annual Conference of the psychological Association of South Africa, Stellenbosch, 2 October.

Beukes, J.A. (1994). Die sielkundige kontrak: wedersydse verwagtings tydens die aanvangsfase van militêr-akademiese studies. Ongepubliseerde M Econ-verhandeling. Stellenbosch: Universiteit van Stellenbosch.

Beukes, J.A. \& Vos, H.D. (1996). Die sielkundige kontrak: Wedersydse verwagtings tydens die aanvangsfase van militêr-akademiese studies. Journal of Industrial Psychology, $22(2), 32-37$.

Cooke, H.J. \& Basson, J.S. (1992). Die verband tussen werkswaardes en organisasieverbondenheid. Paper presented at the 10th annual Conference of the Psychological Association of South Africa, Stellenbosch, 2 October.

Dean, R.A. (1984). Reality shock: A predictor of the organisational commitment of professionals. Research Monograph. Lexington, VA: Washington and Lee University, School of Commerce, Economics and Politics.

Dhammanungune, S. (1990). A theory and model of the psychological contract in organisations. Unpublished D. Phil-thesis, United States International University, San Diego.

Goddard, R.W. (1988). Inside the psychological employee. Management World, 17(2), 24-26.

Gulliksen, H. (1950). Theory of mental tests. New York: John Wiley.

Griffen, R.W. \& Bateman, T.S. (1986). Job satisfaction and organisational commitment. International Review of Industrial and Organisational Psychology, 157-188.

Guzzo, R.A. \& Noonan, K.A. (1994). Human resource practices as communications and the psychological contract. Human Resource Management, 33(3), 447-462.

Editor. (1997). Jobless figure not as bad as was generally believed - survey, Business Day, 7 December.

Hall, D.T. (1996). Protean careers of the 21st Century. Academy of Management Executive, 10(4), 8-16.

Hallier, J. \& James, P. (1997). Middle managers and the employee psychological contract: Agency, protection and advancement. Journal of Management Studies, 34 (5), $703-$ 728 .

IMD. (1997). World Competitiveness Report: 1997.

Johnston, G.P. \& Snizek, W.E. (1991). Combining head and heart in complex organisations: A test of Etzioni's dual compliance structure hypothesis. Human Relations, 44(12), $1255-1272$.

Kamfer, L., Venter, D.J.L. \& Boshoff, A.B. (1994). The dimensions of employee commitment: A South African confirmatory factor analysis. Journal of Industrial Psychology, $20(2), 1-7$.

Kaiser, H.F. (1961). A note on Guttman's lower bound for the number of common factors. British Journal of Statistical Psychology, 14 (1), 1.

Kotter, J.P. (1970). The psychological contract: Expectations and the joining-up process. Unpublished Master's Thesis, The Sloan School of Management, Massachusetts Institute of Technology, Cambridge.

Kotter, J.P. (1973). The psychological contract Managing the joining-up process. California Management Review, 15(3).

Levinson, H. (1962). Men, management and mental health. Cambridge, Massachusetts: Harvard.

Lusero, M.A. \& Allen, E. (1994). Employee benefits: A growing source of psychological contract violations. Human Resource Management, 33(3), 425-46.

Littlefield, D. (1997). Struggling to firm up a working definition. People Management, 3(9), 17.

Mathieu, J.E. \& Zajac, D.M. (1990). A review and meta-analysis of antecedents, correlates and consequences of organisational commitment. Psychological Bulletin, 108(2), 171-194.

Morrison, D.E. (1994). Psychological contracts and change. Human Resource Management, 33 (3), 353-378.

Mowday, R.T., Steers, R.M., \& Porter, L.W. (1979). The measurement of organisational commitment. Journal of Vocational Behaviour, 14(2), 224-247.

Mowday, R.T., Porter, L.W. \& Steers, R.M. (1982). Employeeorganisational linkages. The psychology of commitment absenteeism and turnover. New York: Academic Press.

Myburg, P. \& Slabbert, J.A. (1998) The search for the missing link: The psycho-social contract. Unpublished M Com Article. Johannesburg, Randse Afrikaanse Universiteit.

Porter, L.W. (1970) The etiology of organisational commitment. Unpublished Paper, University of California at Irvine. 
Robinson, S.L. (1996). Trust and breach of the psychological contract. Administrative Science Quartely, 41 (4), 574-599.

Robinson, S.L., Kraatz, M.S. \& Rousseau, D.M. (1994). Changing obligations and the psychological contract: A longitudinal study. Academy of Management Journal, 37 (2), 137-152

Robinson, S.L. \& Morrison, E.W. (1995). Organisational citizen behaviour: A psychological contract perspective. Journal of Organizational Behaviour, 16, 289-298.

Robinson, S.L. \& Rousseau, D.M. (1994). Violating the psychological contract: Not the exception but the norm. Journal of Organizational Behaviour, 15, 245-259.

Roodt, G.J. (1992). Organisasieklimaat as voorspeller van organisasieverbondenheid, ' $n$ studie aan 'n tersiêre onderwysinrigting. Paper presented at the 10th annual Conference of the psychological Association of South Africa, Stellenbosch, 2 October.

Rousseau, D.M., (1989). Psychological and implied contracts in organisations. Employee Responsibilities and Rights Journal, 2 (2), 121-139.

Rousseau, D.M., (1996). Changing the deal while keeping the people. Academy of Management Executive, 10 (1), 50-59.

Rousseau, D.M. \& Greller, M.M. (1994). Guest editor's overview: Psychological contracts and human resource practices. Human Resource Management, 33 (3), 383-384.

Rousseau, D.M. \& Parks, D.M. (1993). The contracts of individuals and organisations. In Cummings, L.L. \& Staw, B.M. (Eds), Research in Organizational Behaviour, 15, 1-43.

Rousseau, D.M. \& Wade-Banzoni, K. (1994). Linking strategy and human resource practices: How employee and customer contracts are created. Human Resource Management, 33 (3), 463-489.

Schein, E.H. (1965). Organisational Psychology. Englewood Cliffs, NJ: Prentice- Hall.

Schein, E.H. (1978). Career dynamics: Matching individual and organisational needs. Philippines: Addison Wesley.

Schepers, J.M. (1992). Toetskonstruksie: Teorie en praktyk. Johannesburg, Randse Afrikaanse Universiteit.

Sims, R.R. (1994). Human resource management's role in clarifying the new psychological contracts. Human Resource Management, 33(3), 373-382.

Slabbert, J.A., (1998). The psycho-social contract as departure point for managing by values. In J.A.Slabbert, J.J.Prinsloo, B.J. Swanepoel \& W. Backer. (Eds), Managing employment relations in South Africa. (pp 1-29) Kaapstad: Butterworth.

Spindler, G.S. (1994). Psychological contracts in the workplace; A lawyer's view. Human Resource Management, 33 (3), 325333.

Veldsman, T.H. (1996). Making the future present tense: Face to face with the changing people management context. People Dynamics, 14(1), 12-18. 